\title{
The Rights To Design:
}

\section{The Protection of Intellectual Property Rights in Designing Contemporary Batik Ornament}

\author{
Agung Zainal Muttakin Raden \\ The Department of Visual Communication Design, \\ Faculty of Language and Art, Universitas Indraprasta PGRI \\ Jakarta, Indonesia \\ agung.zainalmr@gmail.com
}

\author{
Muhammad Iqbal Qeis \\ The Department of Visual Communication Design, \\ Faculty of Language and Art, Universitas Indraprasta PGRI \\ Jakarta, Indonesia \\ qeis.m.i@gmail.com
}

\begin{abstract}
Indonesia is known for its diverse culture and traditions, sporting numerous tangible and intangible cultural heritages. Though living in a rich cultural heritage, the lack of knowledge within Indonesian society regarding intellectual property rights resulted in many violations of copyrighted materials. One of the materials protected by the intellectual property rights was Batik ornament. There are many distinct selection of Batik ornaments, however, not all of them are registered and protected under the intellectual property rights. This is one of the many challenges faced by the Indonesian government to preserve and protect the rich cultural expression of Indonesian people, preventing the act of plagiarism that will potentially harm both the people and the nation. By encouraging the protection of intellectual property rights, Indonesian government has ensured the rights to design as one of the human rights to express themselves and impart their ideas through contemporary Batik ornament designs.
\end{abstract}

Keywords - Intellectual Property Rights; Batik; Contemporary Batik Ornament; Human Rights; Design;

\section{INTRODUCTION}

Batik is one of the intangible cultural heritages recognized by UNESCO. Every region in Indonesia has its own distinct motifs, giving off a unique identity that differs between each region. At first, Batik was an exclusive article for the nobles and gentries. The Batik culture and its industry started when the Batik was brought out from the palace of Yogyakartan Sultanate (Keraton Yogyakarta) and gradually used by ordinary people [1]. Batik industry then prospered and was able to compete with other ornamental fabrics and clothes in the international world. The industry started at the Batik center of Prawirotaman and Tirtodipuran in Yogyakarta and spread across the region as time goes by. Aside of Yogyakarta, another prominent Batik industry was centered in Surakarta in the Laweyan and Kauman region. The industry then spread to Cirebon, Pekalongan, Lasem, and out of Java Island to the west (Jambi and Bengkulu in Sumatra Island) and the east (Nusa Tenggara or Lesser Sunda Islands).

There are initially two different techniques in producing the Batik clothes up until 1518, as written in Sañ Hyan Siksa Kandan Karəəsian (SSKK) [2]. The first is a term 'tulis' which refers to the ornamental done by writing into the fabrics. This is the process that was translated by Holle (1867) as 'Batik'. The second is a term 'kain' which refers to the ornamental done by weaving into the fabrics. Later on, the emerging Batik industry used two different processes to produce Batik; Batik Tulis which was done by drawing the ornaments into the fabrics and Batik Cap which was done by pressing the premade stamps into the fabrics. These emerging Batik industries need a protection to exert their rights to keep producing Batik, not just for economic reasons but also for cultural reasons. As one of the intangible cultural heritage, Batik must be supported by all the stakeholders to preserve the rich cultural expression of Indonesian people and the distinct identity found within each of the region in Indonesia. one of the options available to support Batik can be found under the banner of intellectual property rights which consists of: copyright, patent, brand, trade secret, franchise, license and royalty, industrial design, integrated circuit topography, protection of plant varieties and genetic engineering, and internet and domain names [3].

Batik is a work of art that is also a tradition in Indonesian culture across generations. In order to preserve the traditions while protecting the rights to make an art, Indonesian government need to accommodate and regulate this cultural heritage under the legal binding. As of 2017, the safeguarding of traditional culture in the form of copyright falls under art. 10 clause 2 in the Law of the Republic of Indonesia No. 28 of 2014 on Copyright, specifically: "The State holds the copyright for folklore and other works of culture that are commonly owned such as stories, legends, folk tales, myth, chronicles, folk song, handicraft, folk dance, calligraphy, and so on" [4]. Within this regulation, copyrighted materials can be divided into two; copyright for original work and copyright for derivative work [5]. The rights for copyrighted original works are given to the creator such as book author, song composer, poets, and contemporary Batik ornament designer. Meanwhile, the rights for copyrighted derivative works are given through permission granting, license buying, or grants and inheritance.

The art. 1 clause 1 in the Law of the Republic of Indonesia No. 19 of 2002 stated that copyright is the exclusive rights for the creator or the recipient the right to publish or reproduce the creations or give permission for it by not reducing the restrictions according to the laws and regulations. The principle behind the law enforcement in Indonesia is the 
acknowledgement and the protection of human rights that stems from the constitutional state under the guiding principle of Pancasila [6]. The term copyright first stated in the 1886 multilateral treaty in Paris and later was revised in 1971. This treaty, resulted from the Berne Convention for The Protection of Literary and Artistic Work, laid down the foundation to regulate the protection of rights, including the rights for the creator, the period, and the limitation to copyrights [6].

The way to intellectual copyright protection in the 20th century was marked by The Hague Agreement Concerning the International Deposit of Industrial Designs in November 6th, 1925 and the acknowledgement of freedom of artistic creation under the principle of freedom of opinion and expression as human rights in the Universal Declaration of Human Rights in 1948 [7]. The lack of dissemination on the importance of copyright in Indonesia resulted in the lack of knowledge within Indonesian society regarding copyright act, specifically among artists and designers. Many artists and designers are prone to be a victim of plagiarism or plagiarizing other's artwork without knowing about the significance of copyrighted materials. Furthermore, the law enforcement regarding the intellectual property rights are still largely ignored in Indonesia. This can bring harms to the otherwise complicated nature of the work of arts.

Copyright infringement and plagiarism can weaken the rich expression and weaken the grips of regulation which seek to protect the rights to design, especially regarding contemporary Batik ornament with its status as a work of art and a tradition in Indonesian culture. In the past few years, the awareness on the importance of copyright is becoming more prevalent, especially in the academic fields. Many universities established a centre for intellectual property rights to disseminate the importance of copyrighted materials and push their academic members to register their creations to be approved by the Ministry of Law and Human Rights of Indonesia.

\section{DISCUSSION}

Motifs are the main element in an ornament. Through the usage of motifs, we can identify ornaments from each other. The motifs used in an ornament usually derived from the shape and form found in the nature as a representation of the material dimension [6]. These motifs than will create a distinct theme and construct a basic idea, becoming an ornament which is rooted from the word ornare meaning to decorate [6]. Aside of the traditional ornament containing the classic Batik motifs, the copyright protection can also be given to the newly designed contemporary Batik ornament. In this discussion, this paper will observe six contemporary Batik ornaments that have been approved by the center of intellectual property rights. These six contemporary Batik ornaments are designed using the motifs designed from the shape found in nature such as dragon fruits, flowers, birds, and trees, combined with the classic Batik motifs such as Kawung and Parang.
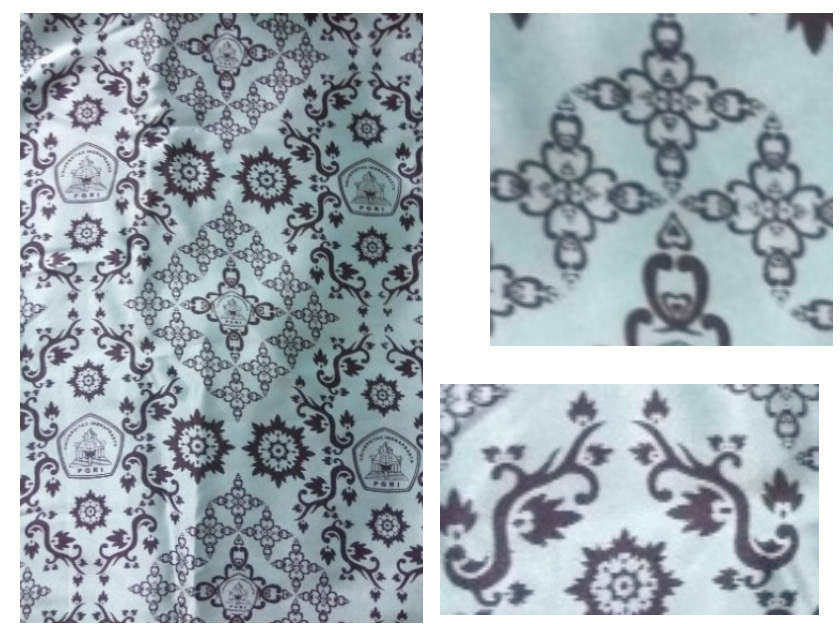

Fig. 1. Contemporary Batik Ornament by Muja Wahidin

Figures 1 shows a contemporary Batik ornament designed by Muja Wahidin (No.HAKI EC00201700979). In this ornament, the motifs of dragon fruit and vine tendrils are combined with the classic motif of Patra. Patra is a motif that was inspired by floral pattern and leaves that were arranged repeatedly. Overall the ornament was rich on floral motifs. These floral motifs found in this ornament are not meant to symbolize any cultural values. Rather, the motifs were arranged so that the Batik ornament will emphasize on the concept of the beauty of nature. Aside of that, the layout was arranged so that the motif will enhance the ornament's aesthetic as a whole when applied into the fabrics. While this contemporary Batik ornament was designed in May 17th, 2008, it was not until April 22nd, 2017 that it got an approval to be included in the protection of intellectual property rights from the Ministry of Law and Human Rights of the Republic of Indonesia.
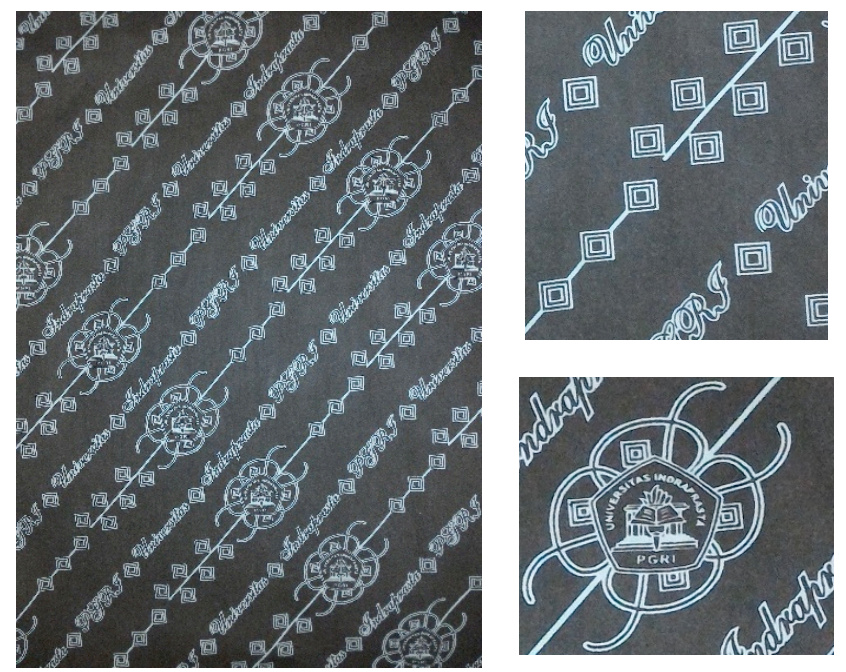

Fig. 2. Contemporary Batik Ornament by Rina W. W and Febrianto S

Figures 2 shows a contemporary Batik ornament designed by Rina Wahyu Winarni and Febrianto Saptodewo (No.HAKI EC00201700981). In this ornament, the motifs of diamond, a stylization of vines and flowers, and text based motif are 
combined with the classic motif of Parang. Parang is one of the sacred motifs in Javanese culture as it was once can only be used to the fabrics meant for religious rituals [6]. The ornament was designed in a diagonal grid using figure and ground principle (light color on top of dark medium) to give a strong dramatic sense. This symbolizes strength and fortitude to grow. This contemporary Batik ornament was designed in May 15th, 2010 and got the approval to be included in the protection of intellectual property rights from the Ministry of Law and Human Rights of the Republic of Indonesia in April 22nd,2017.

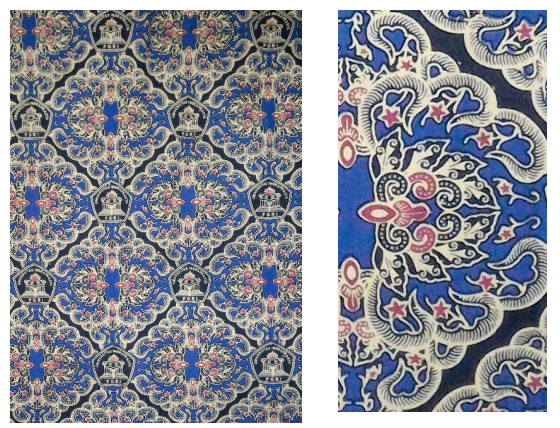

Fig. 3. Contemporary Batik Ornament by Dendi Pratama

Figures 3 shows a contemporary Batik ornament designed by Dendi Pratama (No.HAKI EC00201700990). This ornament was rich on animal motif sporting the mythical bird of Garuda, the national symbol of the Republic of Indonesia. Garuda is a mythical bird that was mentioned in the Hindi chronology of Mahabharata and the epic of Ramayana. Garuda symbolizes power as it is a sacred mount of Vishnu, one of the most important gods in Hindu. The Garuda motif in this ornament was designed by stylizing the shape of the bird, incorporating a classic motif called Mirong [6]. The layout was arranged repeatedly in a diamond pattern to give a balanced sense. This contemporary Batik ornament was designed in May 19th, 2012 and got the approval to be included in the protection of intellectual property rights from the Ministry of Law and Human Rights of the Republic of Indonesia in April 24th, 2017.
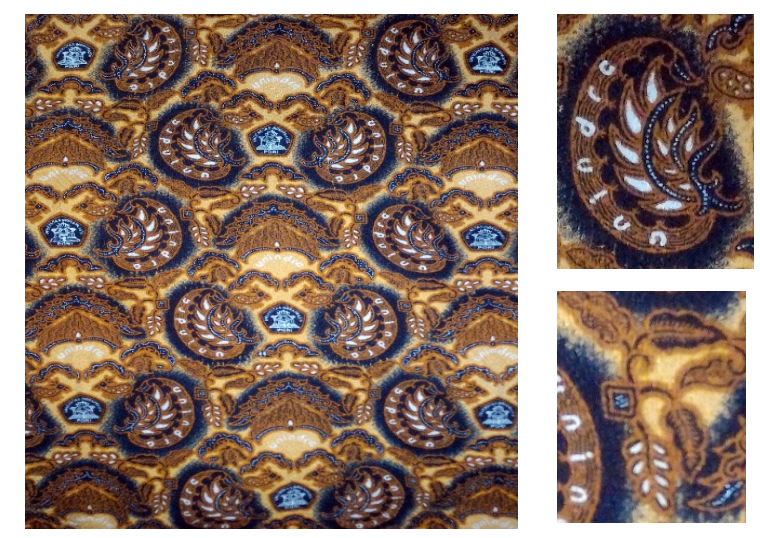

Fig. 4. Contemporary Batik Ornament by Dendi Pratama
Figures 4 shows another contemporary Batik ornament designed by Dendi Pratama (No. HAKI EC00201700992). This ornament also sports the mythical bird of Garuda, albeit only showing one half of its body in the form of its wings. This motif was combined with a stylization of Kala, a monstrous giant with glaring big eyes and sharp teeth from Hindi mythology and the motifs consisted of rice paddy and the classic motif of Patra. In the Hindu mythology, Kala symbolizes the giant of heaven [6]. The wings of the Garuda in this ornament incorporated a classic motif called Lar. Lar in Javanese culture symbolizes power and authority and used to be limited only for the nobles and gentries of Yogyakarta Sultanate. This ornament combined a mythical animal, imaginary monster, and floral theme prominent in Old Javanese culture with the layout being arranged by piling up the motifs repeatedly, depicting the mountainous region of Javanese island. This contemporary Batik ornament was designed in May 17th, 2014 and got the approval to be included in the protection of intellectual property rights from the Ministry of Law and Human Rights of the Republic of Indonesia in April 24th, 2017.
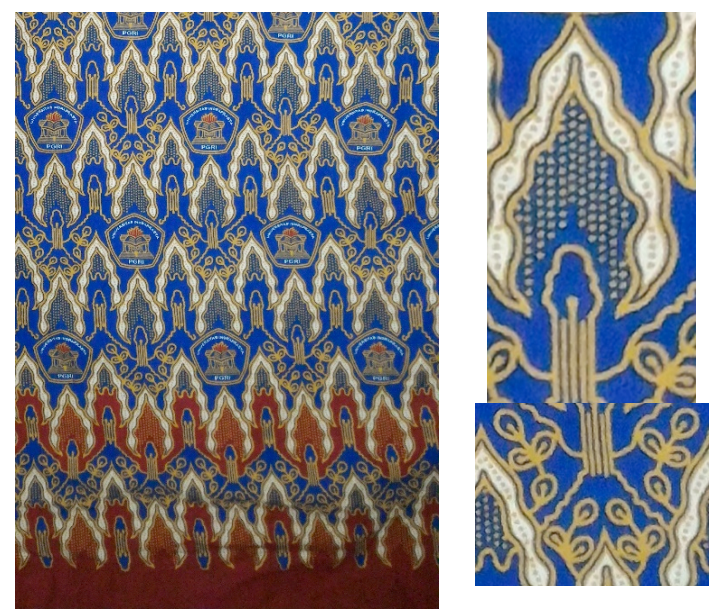

Fig. 5. Contemporary Batik Ornament by Dendi Pratama

Figures 5 shows a contemporary Batik ornament designed by Yasmine (No.HAKI EC00201704329). This ornament combined the classic motif called Hayat with floral motif of vine tendrils. Hayat is a motif that symbolizes life after death, the eternal cycle of life, and prosperity [6]. This motif was prominently used in Wayang, a Javanese shadow puppet, in the form of Gunungan. Gunungan symbolizes the world and the after world. It represents the order and the chaos, beginning and ending. This idea was expressed within the batik by using the color placement in the layout with the red at the bottom representing chaos while the blue at the top portion representing order. Among the five contemporary Batik ornaments observed in this paper, this ornament received the protection on intellectual property rights in the shortest time. This contemporary Batik ornament was designed in May 14th, 2016 and got the approval to be included in the protection of intellectual property rights from the Ministry of Law and Human Rights of the Republic of Indonesia in October 12th, 2017. 


\section{CONCLUSION}

The work of arts as cultural expression in the form of Batik ornament is a culmination of time, effort, and ideas combined with artistic approaches of the human minds. By observing these five contemporary Batik ornament, we can see the rich cultural expression that gives the intangible culture a tangible form. Designing and creating the work of arts as a form of expression is a right for every human. By encouraging the protection of intellectual property rights, Indonesian government has ensured the rights to design as one of the human rights to express themselves and impart their ideas through contemporary Batik ornament designs. This encouragement, in turn, should be promoted and disseminated so that the people living in the rich cultural heritage of Indonesia can protect themselves from plagiarism and other related threat. This protection will also benefit the Indonesian government as a way to exert its democratic influence by granting the protection of the human rights to its people while also enriching the nation of its cultural expression. This will leads Indonesia to become a leading figure in promoting the protection of diversity and multicultural and intercultural interest in the international world that grew more and more xenophobic. With the protection on intellectual property rights, Indonesia will gain a momentum that can stimulate the economic growth via the creative industries, gaining the trust of the international world which is needed to further develop a better deal in the international trade [9].

\section{ACKNOWLEDGMENT}

We thank all the designers who contributed their contemporary Batik ornament designs: Muja Wahidin, S.Sn, Dra. Rina Wahyu Winarni, M.Si, Febrianto Saptodewo, S.Sn., M.Ds, Dendi Pratama, S.Sn., M.M., M.Ds, and Yasmine. We also thank Ahmad Faiz Muntazori, M.Sn as the head of the center for HKI in Unindra. We would also like to show our gratitude for Dr. Khamami Zada, M.A as a lecturer and researcher in the Faculty of Sharia and Law, Universitas Islam Negeri that provided us with the opportunity to present this paper.

\section{REFERENCES}

[1] A. Z. M. Raden and M. I. Qeis, "Vernacular Typography on the Batik Label as a Representation of Typeface Diversity," in Typoday 2017 "Typography and Diversity", Colombo, 2017.

[2] A. Gunawan, "Wastra Dalam Sastra Sunda Kuna," in Seminar Internasional Pernaskahan Nusantara, Surakarta, 2017.

[3] Nahrowi, "Plagiat dan Pembajakan Karya Cipta dalam Hak Kekayaan Intelektual," Salam; Jurnal Filsafat dan Budaya Hukum, vol. 1, no. 2, pp. $227-238,2014$

[4] S. E. V. Teresha, "Efektifitas Pengaturan Hukum Hak Cipta Dalam Melindungi Karya Seni Tradisional," Jurnal LPPM Bidang EkoSosBudKum, vol. 2, no. 2, pp. 1-12, 2015.

[5] U. Hasan and S. , "Perlindungan Hukum Terhadap Hak Cipta Menurut Undang-Undang Nomor 19 Tahun 2002," Jurnal Ilmu Hukum, vol. 4, no. 1 , pp. 1-15, 2013

[6] A. Sunaryo, Ornamen Nusantara Kajian Khusus Tentang Ornamen Indonesia, Semarang: Dahara Prize, 2009.

[7] P. Thalib, "Perlindungan Hukum Terhadap Pemegang Hak Cipta Dan Pemilik Lisensi Rekaman Berdasarkan Undang-Undang hak Cipta," Yuridika, vol. 28, no. 3, pp. 351-360, 2013.

[8] D. Kusmawan, "Perlindungan Hak Cipta Atas Buku," Perspektif, vol. 19, no. 2, pp. 137-143, 2014.

[9] D. Samsudin, Hak Kekayaan Intelektual dan Manfaatnya Bagi Lembaga Litbang, Jakarta: Direktorat Jenderal Kekayaan Intelektual Kementerian Hukum dan Hak Asasi Manusia, 2016. 